\title{
Population Connectivity and Larval Dispersal \\ Using Geochemical Signatures in Calcified Structures
}

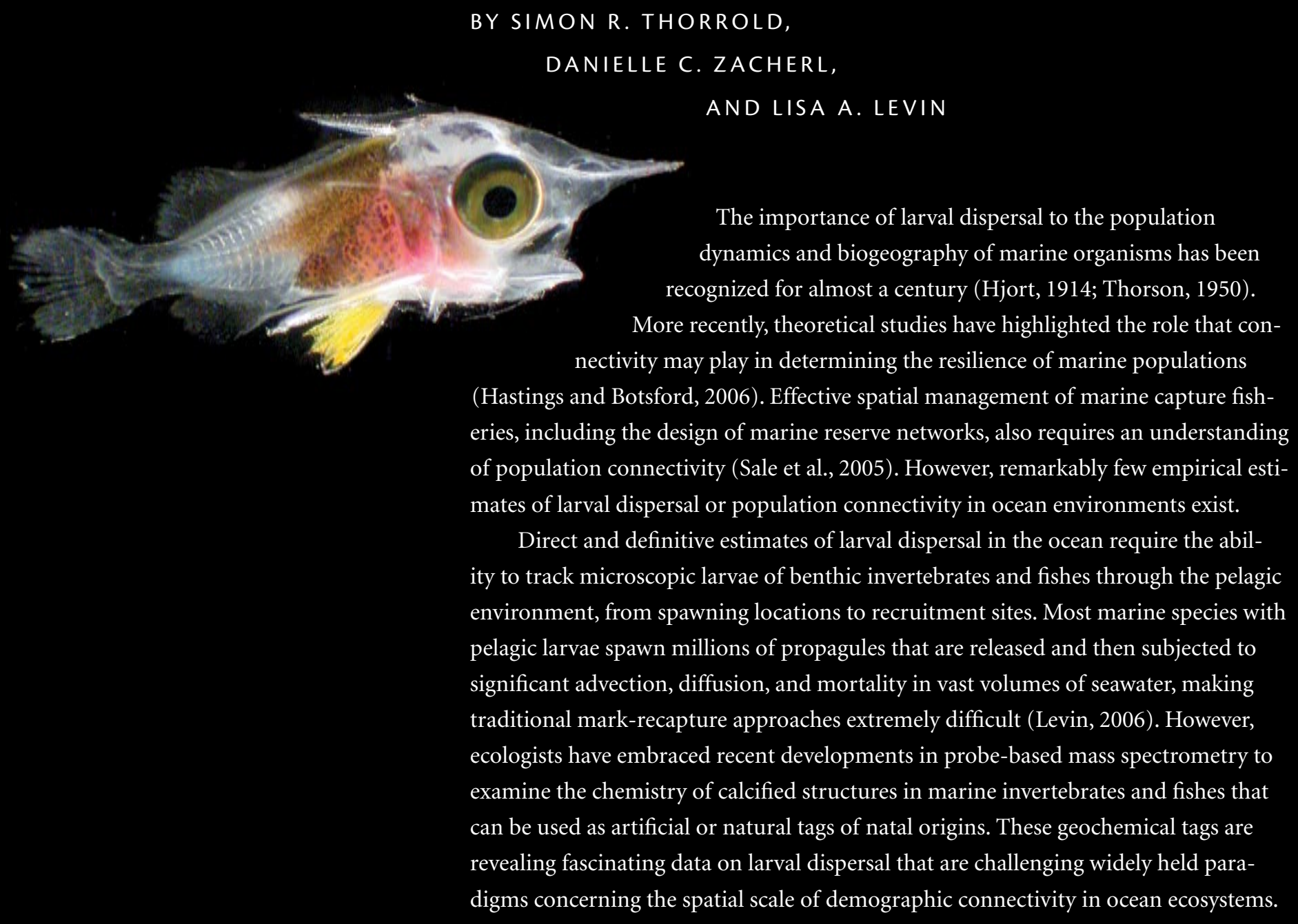




\section{GEOCHEMICAL APPROACHES} Natural Tags

Natural geochemical tags are generated by variations in environmental conditions, including temperature, salinity, and seawater chemistry, that are subsequently recorded by the elemental or isotopic composition of calcified structures (see Box 1). Therefore, shells, fish ear-stones (called otoliths), and statoliths (the invertebrate analog to otoliths) may act as dated "flight recorders" because as organisms disperse across gradients in seawater composition or temperature, their travels are being constantly recorded by the chemistry of the calcified structure. Likewise, larvae developing in areas that have differing seawater characteristics build calcified structures whose elemental compositions reflect their sources (Zacherl et al., 2003a; Becker et al., 2007). Typically, geochemical tags consist of either a combination of minor and trace elements expressed as a ratio to $\mathrm{Ca}$ (e.g., $\mathrm{Mg} / \mathrm{Ca}, \mathrm{Mn} / \mathrm{Ca}, \mathrm{Sr} / \mathrm{Ca}$, and $\mathrm{Ba} / \mathrm{Ca}$ ), or stable isotope ratios such as $\delta^{18} \mathrm{O}$ (Killingley and Rex, 1985) and $\delta^{87} \mathrm{Sr}$ (Barnett-Johnson et al., 2005).

The ability of natural geochemical tags to track larval movement depends upon the existence of substantial variation in the elemental composition of those tags among locations of interest (Thorrold et al., 2002). Many studies using geochemical tags have focused on species inhabiting estuaries because of significant variation in the elemental composition of their calcified structures (e.g., Swearer et al., 2003), probably due to substantial differences in salinity, temperature, and water chemistry among estuarine waters. Variation in water chemistry among estuaries is a function of coastal geology, sources of pollution, atmospheric deposition, and variable inputs from local watersheds. In southern California, for example, because of heavily urbanized development, rainwater runoff should contribute high concentrations of trace elements associated with anthropogenic activity into the estuaries and nearshore waters. The magnitude of input of these trace elements is a function of land use, the amount of impermeable surface area within a watershed, number and size of rivers, and frequency of rain events (Ackerman and Schiff, 2003). Broadening consideration to the entire west coast of the United States, watersheds in Washington and Oregon regularly receive $>100$ inches of rain annually, while watersheds in southern California rarely see $>50$ inches annually (National Weather Service, 1961-1990 average annual rainfall). Because of this extreme variation in land use, geology, and runoff contributions typically associated with estuaries, these habitats would appear to provide ideal locations for generation of a natural geochemical tag (see "Progress to Date" below).

Less attention has focused on using geochemical tags in open-coast species. The limited emphasis on coastal ocean habitats is probably because gradients in oceanographic conditions can be more subtle, thus complicating the generation of unique geochemical tags. For example, Gillanders et al. (2001) found little variation in otolith chemistry of two-banded bream among locations and sites that ranged from $\sim 10$ to $>100 \mathrm{~km}$ from one another along the coast of Spain. They attributed the lack of variation in otolith chemistry to the lim- ited number of major rivers within the study location and to low rainfall and its associated runoff. However, locations of convergence between distinct ocean currents (e.g., at Point Conception in central California and at Cape Hatteras in North Carolina, USA) are characterized by sharp gradients in temperature and, to a lesser extent, salinity, making generation of distinctive geochemical tags likely (Zacherl, 2005). Seawater elemental composition may also vary among locations at smaller spatial scales (e.g., Becker et al., 2005) due to differences in coastal geology, mesoscale oceanography, and variable inputs from local watersheds.

The tremendous advantage to using natural geochemical tags is that every larva is potentially tagged, eliminating any concerns arising from dispersion of tagged larvae and subsequent low recapture rates. However, there can be a significant uncertainty in interpreting the elemental variation in tags among locations. Unless obvious and strong broad-scale regional gradients in tag composition exist, the approach necessitates substantial sampling effort to ensure that the geochemical tags of all potential source populations have been characterized.

\section{Artificial Tags}

Calcified tissues are also ideal repositories for artificial chemical markers that are used to tag embryos or lab-reared larvae before dispersal from natal locations (Jones et al.,1999; Moran and Marko, 2005; Thorrold et al., 2006). Fluorescent compounds such as tetracycline or calcein, elemental markers (e.g., rare earth elements), and radioactive isotopes have all been used to tag 
calcified structures by immersing developing larvae (or their food) in a solution containing the target marker (reviewed by Thorrold et al., 2002). The marked larvae can then be released from a source population and recaptured at a destination of interest, where they are screened for presence of the artificial tag. To overcome high larval mortality rates and diffusive processes that can dilute the concentrations of tagged larvae substantially, significant portions of the total larval population must be tagged. To estimate connectivity, the proportion tagged out of the total number of larvae spawned by the focal population during the experiment must be estimable. Artificial tagging has, therefore, been used successfully to estimate rates of larval retention to local populations (Jones et al., 1999, 2005, and see "Emerging Technologies" below), but has yet to be applied to examinations of connectivity among different subpopulations.

\section{PROGRESS TO DATE}

Although initially applied to fish otoliths (Campana, 1999), geochemical tagging methods have now been expanded to include statoliths, protoconchs (larval shells) of molluscs (Zacherl et al., 2003a; Arkhipkin et al., 2004), and whole bodies of decapod larvae (DiBacco and Levin, 2000). However, applications for many taxa remain difficult and labor intensive, and only a handful of studies have successfully examined larval connectivity using natural geochemical tags.
Spatial Variability in Trace

Element Signatures

A key initial objective in using natural geochemical tags, and a prerequisite to its successful application to population connectivity, has been to identify those habitats, oceanographic conditions, or specific locations that impart distinct multi-elemental signatures to larvae. As mentioned above, estuaries provide the ideal variation in chemical and physical characteristics to generate significant variation in geochemical tags. For instance, a clear distinction between embayment and nearshore coastal otolith elemental signatures has been documented for larval California halibut (Forrester and Swearer, 2002) and English sole (Brown, 2006) on the

\section{BOX 1. CSI SEAWATER-DO CALCIFIED STRUCTURES INTEGRATE SEAWATER PROPERTIES?}

Use of geochemical tags is premised on the notion that the chemistry of calcified structures in some way reflects physiochemical properties of the surrounding seawater in which the calcified structure was formed. Results from controlled laboratory experiments on gastropod larvae by Zacherl et al. (2003b) and on fish larvae by Bath et al. (2000) clearly supported this assumption and yielded predictable results (Figure A-1). In their experiments, both groups manipulated concentrations of $\mathrm{Ba} / \mathrm{Ca}$ in rearing seawater, raised larvae for several weeks under experimental conditions, and then analyzed whole larval calcified structures using inductively coupled plasma mass spectrometry (ICP-MS). Linear relationships between concentrations of elements in seawater and in biogenic aragonite are common and have been documented for many elements including $\mathrm{Ba}, \mathrm{Sr}$, and Mg (e.g., Lorens and Bender, 1980; Elsdon and Gillanders, 2003).

Temperature and salinity also predictably influence element uptake into otoliths and statoliths (e.g., Martin et al., 2004; Zumholz et al., 2007). The combined results of all culturing studies suggest that calcified otoliths, statoliths, and protoconchs, like foraminifera tests (Lea et al., 1999), can indeed reliably integrate information about seawater physical and chemical properties.
However, there is still some mystery involved with how simple and predictable findings from larval culturing studies play out in a field setting, where calcified structures form under the influence of several interacting factors. Therefore, recent culturing experiments have focused on examining the interactive effects of two or more factors (e.g., Milton and Chenery 2001; Martin and Thorrold, 2005) and on ranking their relative importance (Elsdon and Gillanders; 2004; Lloyd et al., in press). Further, there is very recent evidence that not only seawater physical and chemical properties but also maternal transmission of elements can influence the elemental composition of larval calcified structures. For example, there is evidence that trace elements contained in the egg can be incorporated into larval-fish otoliths (Kalish, 1990; Thorrold et al., 2006) and into larval-gastropod statoliths (Lloyd et al., in press). This knowledge complicates our ability to draw simple conclusions about the physical environment based upon the chemistry of calcified structures but provides an exciting venue for future Calcified Structure Investigations. 
Pacific coast. Fodrie (2006) found similar patterns in juvenile California halibut otoliths, but went a step further in documenting distinct signatures for embayments with different geomorphologies and for open-coast habitat. These findings were employed to address the movements of juveniles within bays, and allowed increasing refinement of nursery habitat determination for successful subadults as well as evaluation of the demographic consequences of using different nursery habitats.

Detecting geochemical differences imparted to pelagic larvae that disperse along the open coasts of continents has proved a greater challenge. Recent progress suggests that subtle differences in water masses and eddies, upwelling, temperature, or watershed influence may provide the needed chemical variation to allow for the application of natural geochemical signatures (e.g., Zacherl, 2005). For instance, natal sites of larval rockfish (Sebastes atrovirens) were distinguished between mainland and island sites by $\mathrm{Zn} / \mathrm{Ca}, \mathrm{Sr} / \mathrm{Ca}, \mathrm{Ba} / \mathrm{Ca}$, and $\mathrm{Pb} / \mathrm{Ca}$ signatures in prehatch otoliths; mainland sites only $10 \mathrm{~km}$ apart also showed significant differences in elemental signatures (Warner et al., 2005).

\section{Identifying Natal Origins}

The ability to address the question, "where did newly recruited individuals come from?" is a real strength of geochemical tags, and distinguishes the method from other indirect approaches to measuring connectivity, including coupled biophysical modeling and population genetics. Despite the potential, there are remarkably few studies that have used geochemical signatures successfully to determine larval origins, although identi-

\section{SIMON R.THORROLD (sthorrold@}

whoiedu) is Associate Scientist, Biology

Department, Woods Hole Oceanographic Institution, Woods Hole, MA, USA.

\section{DANIELLE C. ZACHERL is Assistant}

Professor, Department of Biological Science, California State University, Fullerton, Fullerton, CA, USA. LISA A. LEVIN is Professor, Integrative Oceanography Division, Scripps Institution of Oceanography, La Jolla, CA, USA.

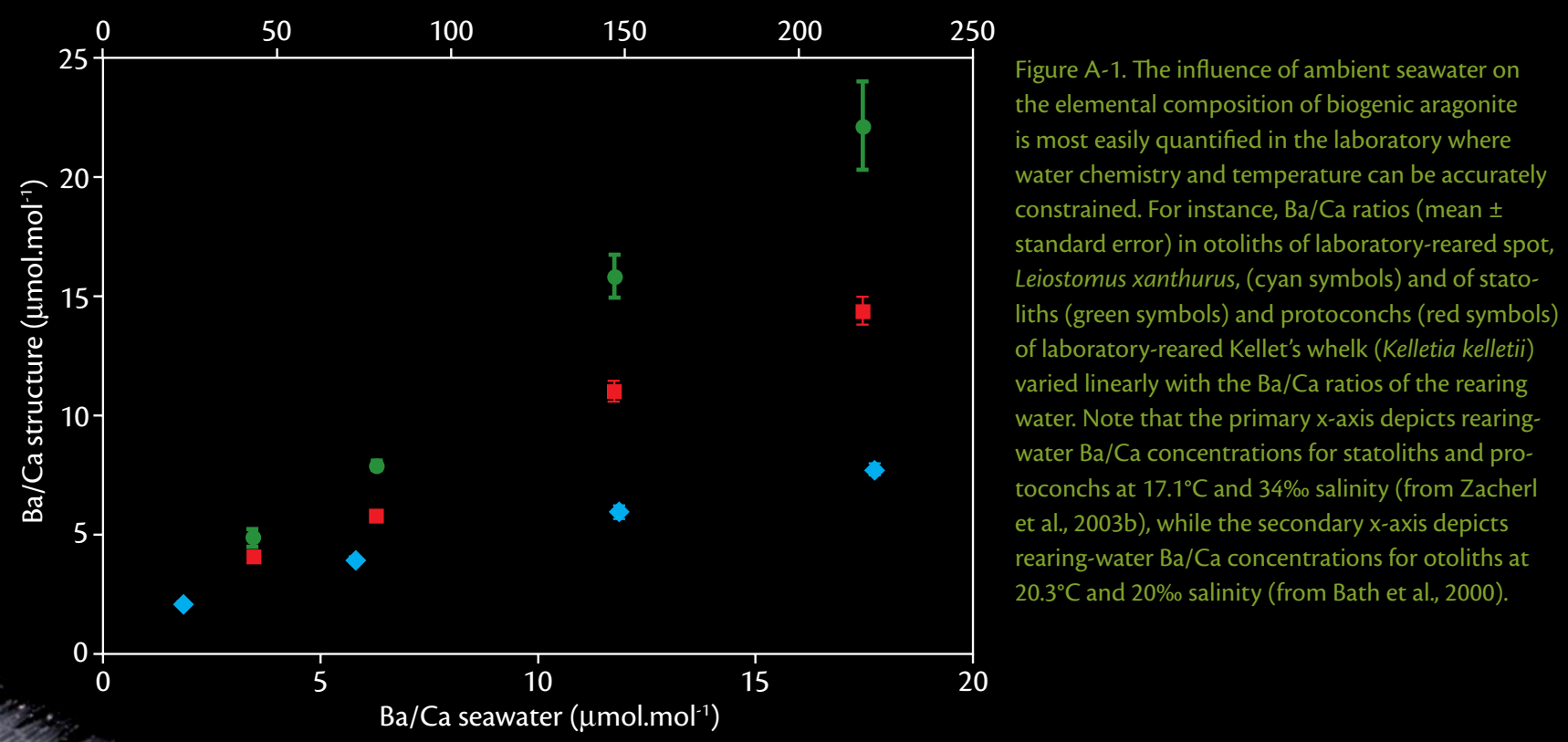


fication of juvenile nursery areas has been achieved in several instances (e.g., Thorrold et al., 2001).

One key question that can be addressed with geochemical markers is the extent to which populations are capable of replenishing themselves through recruitment of locally produced larvae. For the few studies that have succeeded in identifying origins of settled, subadult, or adult individuals, a pattern has emerged suggesting that local retention of larvae, or return of spawning adults to natal sites, may be more prevalent than previously expected
(Caley et al., 1996). The most comprehensive assessments to date have been conducted on coral reef fishes. Using an artificial fluorescent tag incorporated into embryonic otoliths, Jones and co-workers found that from 15 to $60 \%$ of yellow damselfish (Pomacentrus amboinensis) larvae recruiting to Lizard Island, Australia, originated from local reefs (Jones et al., 1999), and up to $42 \%$ of panda clownfish (Amphiprion polymnus) recruited to natal sites around Schumann Island, Papua New Guinea (Jones et al., 2005). Swearer et al. (1999) reported, based on natu- ral tags in otoliths, that up to $50 \%$ of bluehead wrasse (Thalassoma bifascia$t u s)$ recruits on St. Croix were spawned locally. It is noteworthy that the levels of self-recruitment documented by each of the three studies were quite similar despite the fact that yellow damselfish and panda clownfish spawn benthic eggs and their larvae have relatively short pelagic durations, while bluehead wrasse are pelagic spawners whose offspring typically spend 40 to 60 days as pelagic larvae.

Determination of larval origins using geochemical signatures in marine inver-

\section{BOX 2. MUSSELS IN MOTION}

The use of natural geochemical tags in studies of larval connectivity requires knowledge of the signatures imparted to larval structures by specific water masses at different locations. This has been a serious challenge for free-spawning species that do not brood or hold their offspring on the seabed. A solution to this problem is presented in Becker et al. (2007). The authors outplanted laboratory-spawned larvae of mytilid mussels to generate a reference map of chemical signatures at different locations in San Diego County, including open-coast and bay settings along $75 \mathrm{~km}$ of shoreline (Figure B-1). Larvae of two Mytilus mussel species were introduced into PVC "homes" within 12 hours of spawning (before shell formation) and were transported to nearshore moorings where they were allowed to develop for one week. During this period the larvae laid down aragonite shells that retained a chemical signature of the waters in which they developed. The elemental composition of the larval shells was then analyzed using laser ablation inductively coupled plasma mass spectrometry (ICP-MS). After analyzing shell signatures, Becker and co-workers determined that the method resolution for identifying distinct water bodies was greatest at the regional $(20-30 \mathrm{~km})$ scale and for individual bays.
Two weeks after the outplanting, newly settled mussels (one to two weeks old) were collected from intertidal rocks near the outplant moorings. These recruits were 1-2 $\mathrm{mm}$ and retained their larval shell-the protoconch. Recruit mussel tissue was analyzed by a PCR-based assay to identify species (either Mytilus californianus or Mytilus galloprovincialis). The chemical composition of recruit larval shells was determined by laser ablation ICP-MS and individuals of each species at each sampling site were assigned an origin. This information was used to assess larval connectivity patterns for the California mussel and the bay mussel in San Diego County. Differences were found in larval connectivity patterns of the two species (Figure B-1); this was unexpected as their larvae are thought to mix along the San Diego coastline. M. californianus exhibited asymmetric mixing with the majority of larvae originating in the northern part of the study area; there was high self-recruitment in the north and high importation of larvae in the south. M. galloprovincialis recruits had more diverse origins from a mixture of north, south, and bay locations, but with substantial (40\%) self-recruitment. This study provides information about larval connectivity for two species at one time in one region. It offers a first look at the origins of settled invertebrates using elemental signatures in shells, and supports a growing paradigm of limited dispersal, even in species with long-lived larvae. However, many questions remain about the underlying causes of species differences in connectivity, the stability of these patterns over time, and their relevance for other areas within the species' ranges. 
tebrates began with elemental signatures of crab zoea from inside and outside San Diego Bay (DiBacco and Levin, 2000). While analyses confirmed behaviorally enhanced export of larvae (DiBacco et al., 2001) and extensive mixing of larvae from different sources (DiBacco and Chadwick, 2001), the researchers did not address the question of natal origins of new recruits. Recently, natal origins of new recruits were determined in mytilid mussel populations along the coast of southern California (Becker et al., 2007). Bay mussels (Mytilus galloprovincialis) and California mussels
(M. californianus) were found to exhibit differing connectivity patterns and rates of self-recruitment among study sites (see Box 2).

\section{EMERGING TECHNOLOGIES AND FUTURE DIRECTIONS}

The use of geochemical signatures in calcified structures of marine organisms to estimate population connectivity in marine ecosystems is still in its infancy. A number of significant challenges remain before routine estimates of population connectivity in coastal waters will be possible using these approaches.
Nonetheless, exciting new results using natural and artificial geochemical tags clearly demonstrate the potential of the approach (Almany et al., 2007; Becker et al., 2007). We also envisage application of the techniques in novel environments, including hydrothermal vents and other ephemeral habitats in the deep sea, where connectivity is likely to be extremely important to population persistence and maintenance of biodiversity (e.g., Neubert et al., 2006).

Despite some progress, the application of geochemical markers to the study of larval dispersal in marine environ-
A

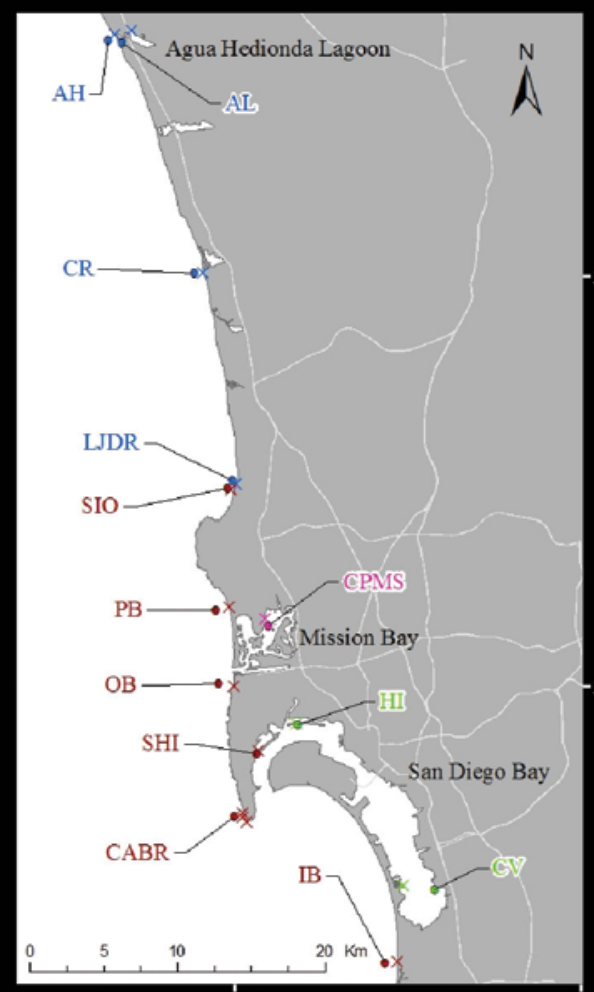

B

Mytilus californianus

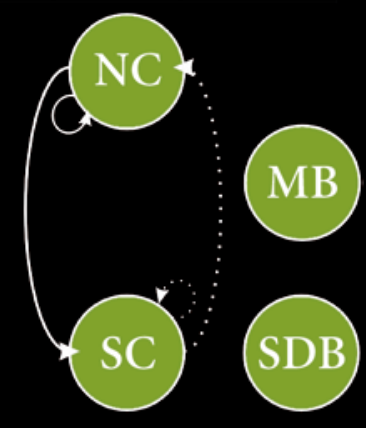

Mytilus galloprovincialis

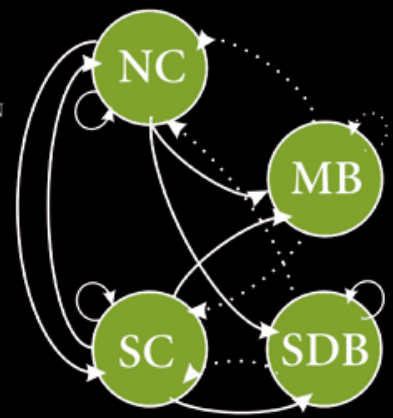

Figure B-1. (A) In the initial phase of a study to examine population connectivity of mussels (Mytilus spp.) along the coast of southern California, larval mussels were outplanted into PVC homes at a number of locations and allowed to develop for one week in ambient seawater. Natal origins of newly settled recruits collected two weeks after the outplanting were then determined based on reference maps of chemical signatures developed from outplanted larvae (from Becker et al., 2007). (B) The resulting schematic diagram of population connectivity along the coast of San Diego County revealed unidirectional movement of larvae from northern to southern locations for M. californianus (top panel), while M. galloprovincialis (bottom panel) populations showed more evidence of local self-recruitment (from Becker, 2005). NC $=$ Northern coastal region (blue sites include $\mathrm{AL}=$ Agua Hedionda Lagoon, $\mathrm{AH}=$ Agua Hedionda, $\mathrm{CR}=$ Cardiff Reef, LJDR = La Jolla Dike Rock). SC = Southern coastal region (red sites include $\mathrm{SIO}=$ Scripps Institution of Oceanography Pier, PB = Pacific Beach (Crystal) Pier, $\mathrm{OB}=$ Ocean Beach Pier, $\mathrm{CABR}=$ Cabrillo National Monument, IB = Imperial Beach Pier, $\mathrm{SHI}=$ Shelter Island). $\mathrm{MB}=$ Mission Bay (pink site, $\mathrm{CPMS}=$ Crown Point Mitigation Site). SB = San Diego Bay (green sites include $\mathrm{HI}=$ Harbor Island and CV = Chula Vista). Labels point to larval outplant stations, and $\mathrm{Xs}$ represent corresponding intertidal recruit collection stations. 
ments remains hampered by technological limitations. Elemental analysis of individual microscopic calcified structures must involve laser ablation of very small amounts of calcified material (i.e., less than $5 \mu \mathrm{g}$ ). Such small quantities of analyte provide a transient signal that is often insufficient for sequential analysis of isotopes with single collector inductively coupled plasma mass spectrometry (ICP-MS) instruments (Strasser et al., in press). However, timeof-flight mass spectrometry (TOF-MS) allows for simultaneous detection of ions over a large mass range and is therefore particularly well suited to analyses of transient signals generated by laser ablation (Vázquez et al., 2002). New developments in laser ablation also offer hope for more accurate chemical analyses of larval shells and otoliths. For instance, UV femtosecond laser systems, likely to ions that are then transported to a mass spectrometer for quantification (Russo et al., 2002). In the future we may see femtosecond lasers coupled to plasma source TOF-MS instruments producing precise and accurate elemental data at spatial resolutions less than $10 \mu \mathrm{m}$. This resolution could allow detailed examination of larval trajectories reflected in the chemical composition of distinct regions of minute larval structures.

As mentioned above, studies attempting to use natural geochemical markers in open marine systems commonly encounter subtle gradients in physical and chemical properties of coastal water masses, at least compared to the stronger elemental signals imparted within river and estuarine systems. Efforts to overcome this problem include refinement of analytical techniques to increase the precision of geochemical variables.

\section{With careful targeting of specific questions}

\section{to be addressed, and of focal species to be}

examined, studies using natural and artificial tags in calcified structures are likely to lead to

\section{significant advances in our understanding of population connectivity in ocean ecosystems.}

be available commercially in the near future, will hopefully improve both the spatial resolution and accuracy of laser ablation ICP-MS analyses (Koch and Günther, 2007). Femtosecond lasers eliminate mass fractionation, at least in theory, during the ablation process and provide for stoichiometric conversion of
However, we may already be at a stage where physiological or ontogenetic controls on the elemental composition of biogenic carbonates may introduce more error into estimates of larval sources from geochemical signatures than the precision of the analytical technique. In the future, researchers are likely to use isotope tracers that are less subject to physiological effects and therefore more accurately reflect ambient values in the environment. The number of these isotope systems available to researchers has increased rapidly with the development of multiple collector arrays on ICP-MS instruments (Halliday et al., 1998). There may also be useful synergies with researchers attempting to develop new temperature proxies in biogenic carbonates based on $\mathrm{Mg}$, $\mathrm{Ca}$, and $\mathrm{Sr}$ isotopes that may not be subject to significant biological fractionation (e.g., Nägler et al., 2000; Fietzke and Eisenhauer, 2006).

Interest continues in artificial tagging approaches for marine larvae because few methods can provide unequivocal estimates of population connectivity in ocean ecosystems. However, the logistic difficulties associated with tagging a large proportion of the total larval production from an area has, until very recently, proved difficult to overcome. The development of a TRAnsgenerational Isotope Labeling (TRAIL) technique, based on maternal transmission of an enriched stable $\mathrm{Ba}$ isotope that is incorporated in the embryonic otoliths of larval fish, may help to overcome this limitation (Thorrold et al., 2006). The TRAIL approach represents a significant advance from earlier artificial tagging methods because it is possible to tag a much higher proportion of the total larval production from an area, the technique can be used on benthic and pelagic spawning fishes, and multiple tags can be applied (Figure 1). The first field test of the method demonstrated substantial (>50\%) self-recruitment of benthic and pelagic spawning fishes to a small coral reef reserve in Papua New 


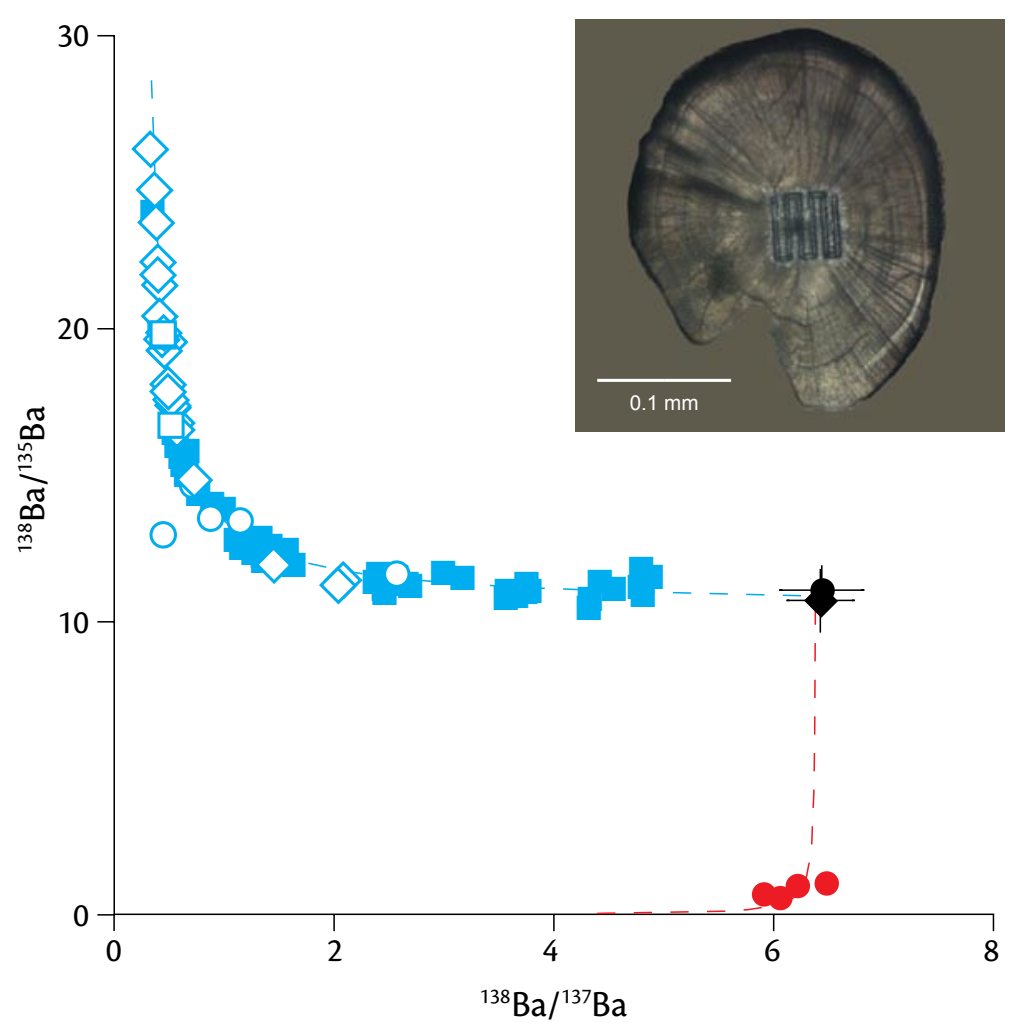

Figure 1. A new approach for marking fish larvae relies upon transgenerational transfer of enriched $\mathrm{Ba}$ isotopes from females to the embryonic otoliths of their offspring. To determine the potential of this approach, black sea bass (Centropristis striata: diamonds), red and black anemonefish (Amphiprion melanopus: squares), and brown-marbled grouper (Epinephelus fuscoguttatus: circles) females were injected with either an enriched ${ }^{137} \mathrm{Ba}$ (cyan symbols) or ${ }^{135} \mathrm{Ba}$ (red symbols) solution (black symbols are mean values $[ \pm 3 \sigma]$ from controls for each species). Larvae spawned after injections were reared for two to four weeks, and laser ablation inductively coupled plasma mass spectrometry was then used to analyze Ba isotope ratios from a $50 \mu \mathrm{m} \times 50 \mu \mathrm{m}$ raster centered on otolith cores from all three species (otolith from A. melanopus shown in insert). Barium isotope ratios in the cores of larval otoliths from injected females plotted close to the theoretical mixing curves (dashed lines) between the enriched isotope spikes and natural Ba ratios, providing conclusive evidence for maternal transfer of the unique Ba isotope tags.
Guinea (Almany et al., 2007). The success of the study was based on the ability to tag a high percentage of all larvae produced in the reserve over a period of two months. The TRAIL method is likely to be particularly useful for species that form spawning aggregations at specific locations and times, and therefore provide the opportunity for a considerable percentage of the total spawning population to be captured.

\section{IMPLICATIONS}

Ultimately, scientists need to provide accurate information on population connectivity, which can be used to optimize spatial management approaches, including marine protected areas (MPAs), for marine-capture fisheries. Although we know of no management plans that have specifically incorporated empirical esti- mates of population connectivity, such information would have been useful when choosing protected-area locations in Australia's Great Barrier Reef Marine Park or the Channel Islands off the coast of California. However, there is also no denying that determining population connectivity using the approaches outlined here is both time-consuming and expensive, and is therefore only likely to be contemplated for a handful of species at any location. One way to maximize the generality of the results would be to use the data to test the performance of coupled biophysical models that are more easily applied to a number of different species over large spatial scales (e.g., Gilg and Hilbish, 2003; Galindo et al., 2006). Similarly, it has proved almost impossible to verify the effectiveness of MPAs without a method for quantify- ing larval export from the reserve to adjacent fished areas. Recent data suggest that the scale at which coral reef fish populations can be both self-sustaining and capable of providing recruitment subsidies is considerably smaller than previously imagined (Almany et al., 2007). Nonetheless, the generality of these results for other systems, and even for coral reefs, is still in question, particularly for grouper and snapper species that contribute disproportionately to artisanal and commercial fisheries on coral reefs. With careful targeting of specific questions to be addressed, and of focal species to be examined, studies using natural and artificial tags in calcified structures are likely to lead to significant advances in our understanding of population connectivity in ocean ecosystems. 


\section{ACKNOWLEDGEMENTS}

Our sincere thanks to the Division of Ocean Sciences at the National Science Foundation for funding larval connectivity research on K. kelletii (OCE 0351860 to DZ), bivalve mussels (OCE 0327209 and 0648656 to LAL), and coral reef fishes (OCE 0424688 to SRT). We thank B.J. Becker, J. Fodrie, and P. McMillan for sharing unpublished data on mytilid mussel and California halibut connectivity. Some of the ideas discussed here grew out of discussion among members of the Coral Reef Targeted Research (CRTR) Program Connectivity Working Group (http://www.gefcoral.org). ⿷匚

\section{REFERENCES}

Almany, G.R., M.L. Berumen, S.R. Thorrold, S. Planes, and G.P. Jones. 2007. Local replenishment of coral reef fish populations in a marine reserve. Science 316:742-744.

Ackerman, D., and K. Schiff. 2003. Modeling storm water mass emissions to the Southern California Bight. Journal of Environmental Engineering 129:308-317.

Arkhipkin, A., S.E. Campana, J. FitzGerald, and S.R. Thorrold. 2004. Spatial and temporal variation in elemental signatures of statoliths from the Patagonian longfin squid (Loligo gahi). Canadian Journal of Fisheries and Aquatic Sciences 61:1,212-1,224.

Barnett-Johnson, R., F.C. Ramos, C.B. Grimes, and R.B. MacFarlane. 2005. Validation of Sr isotopes in otoliths by laser ablation multicollector inductively coupled plasma mass spectrometry (LAMC-ICPMS): Opening avenues in fisheries science applications. Canadian Journal of Fisheries and Aquatic Sciences 62:2,425-2,430.

Bath, G.E., S.R. Thorrold, C.M. Jones, S.E. Campana, J.W. McLaren, and J.W.H. Lam. 2000. Sr and Ba uptake in aragonitic otoliths of marine fish. Geochimica et Cosmochimica Acta 64:1,705-1,714.

Becker, B.J. 2005. The Regional Population Variability and Larval Connectivity of Mytilid Mussels: Conserving the Populations of Cabrillo National Monument (San Diego, CA). Ph.D. Dissertation. University of California, San Diego.

Becker, B.J., F.J. Fodrie, P.A. McMillan, and L.A. Levin. 2005. Spatial and temporal variation in trace elemental fingerprints of mytilid mussel shells: A precursor to invertebrate larval tracking. Limnology and Oceanography 50:48-61.
Becker, B.J., L.A. Levin, F.J. Fodrie, and P.A. McMillan. 2007. Complex larval retention patterns in marine invertebrates. Proceedings of the National Academy of Sciences of the United States of America 104:3,267-3,272.

Brown, J.A. 2006. Classification of juvenile flatfishes to estuarine and coastal habitats based on the elemental composition of otoliths. Estuarine, Coastal and Shelf Science 66:594-611.

Caley, M.J., M.H. Carr, M.A. Hixon, T.P. Hughes, G.P. Jones, and B.A. Menge. 1996. Recruitment and the local dynamics of open marine populations. Annual Review of Ecology and Systematics 27:447-500.

Campana, S.E. 1999. Chemistry and composition of fish otoliths: Pathways, mechanisms and applications. Marine Ecology Progress Series 188:263-297.

DiBacco, C., and L.A. Levin. 2000. Development and application of elemental fingerprinting to track the dispersal of marine invertebrate larvae. Limnology and Oceanography 45:871-880.

DiBacco, C., and D.B. Chadwick. 2001. Assessing the dispersal and exchange of brachyuran larvae between regions of San Diego Bay, California and nearshore coastal habitats using elemental fingerprinting. Journal of Marine Research 59:53-78.

Dibacco, C., D. Sutton, and L. McConnico. 2001. Vertical migration behavior and horizontal distribution of brachyuran larvae in a low-inflow estuary: Implications for bay-ocean exchange. Marine Ecology Progress Series 217:191-206.

Elsdon, T.S., and Gillanders, B.M. 2003. Relationship between water and otolith elemental concentrations in juvenile black bream Acanthopagrus butcheri. Marine Ecology Progress Series 260:263-272.

Elsdon, T.S., and Gillanders, B.M. 2004. Fish otolith chemistry influenced by exposure to multiple environmental variables. Journal of Experimental Marine Biology and Ecology 313:269-284.

Fietzke, J., and A. Eisenhauer. 2007. Determination of temperature-dependent stable strontium isotope $\left({ }^{88} \mathrm{Sr} /{ }^{86} \mathrm{Sr}\right)$ fractionation via bracketing standard MC-ICP-MS. Geochemistry Geophysics Geosystems, doi:10.1029/2006GC001243.

Fodrie, F.J. 2006. Quantifying nursery habitat value for the California halibut Paralichthys californicus: Distribution, elemental fingerprinting and demographic approaches. Ph.D. Dissertation, University of California, San Diego.

Forrester, G.E., and S.E. Swearer. 2002. Trace elements in otoliths indicate the use of open-coast versus bay nursery habitats by juvenile California halibut. Marine Ecology Progress Series 241:201-213.

Galindo, H.M., D.B. Olson, and S.R. Palumbi. 2006. Seascape genetics: A coupled oceanographicgenetic model predicts population structure of Caribbean corals. Current Biology 16:1,622-1,626.

Gilg, M.R., and T.J. Hilbish. 2003. The geography of marine larval dispersal: Coupling genetics with fine-scale physical oceanography. Ecology 84:2,989-2,998.
Gillanders, B.M., P. Sanchez-Jerez, J. Bayle-Sempere, and A. Ramos-Espla. 2001. Trace elements in otoliths of the two-banded bream from a coastal region in the south-west Mediterranean: Are there differences among locations? Journal of Fish Biology 59:350-363.

Halliday, A.N., D.-C. Lee, J.N. Christensen, M. Rehkamper, W. Yi, X. Luo, C.M. Hall, C.J. Ballentine, T. Pettkke, and C. Stirling. 1998. Applications of multi-collector ICPMS to cosmochemistry, geochemistry, and paleoceanography. Geochimica et Cosmochimica Acta 62:919-940.

Hastings, A., and L.W. Botsford. 2006. Persistence of spatial populations depends on returning home. Proceedings of the National Academy of Sciences of the United States of America 103:6,067-6,072.

Hjort, J. 1914. Fluctuation in the great fisheries of northern Europe. Rapports et Procès-Verbaux des Réunions du Conseil International pour l'Exploration de la Mer 20:1-228.

Jones, G.P., M.J. Milicich, M.J. Emslie, and C. Lunow. 1999. Self recruitment in a coral-reef fish population. Nature 402:802-804.

Jones, G.P., S. Planes, and S.R. Thorrold. 2005. Coral reef fish larvae settle close to home. Current Biology 15:1,314-1,318.

Kalish, J.M. 1990. Use of otolith microchemistry to distinguish the progeny of sympatric anadromous and non-anadromous salmonids. Fishery Bulletin 88:657-666.

Killingley, J.S., and M.A. Rex. 1985. Mode of larval development in some deep-sea gastropods indicated by oxygen-18 values of their carbonate shells. Deep-Sea Research 32:809-818.

Koch, J., and D. Günther. 2007. Femtosecond laser ablation inductively coupled plasma mass spectrometry: Achievements and remaining problems. Analytical and Bioanalytical Chemistry 387:149-153.

Lea, D.W., T.A. Mashiotta, and H.J. Spero. 1999. Controls on magnesium and strontium uptake in planktonic foraminifera determined by live culturing. Geochimica et Cosmochimica Acta 63:2,369-2,379.

Levin, L.A. 2006. Recent progress in understanding larval dispersal: New directions and digressions. Integrative and Comparative Biology 46:282-297.

Lorens, R.B., and Bender, M.L. 1980. The impact of solution chemistry on Mytilus edulis calcite and aragonite. Geochimica et Cosmochimica Acta 44:1,265-1,278.

Lloyd, D.C., D.C. Zacherl, G. Paradis, M. Sheehy, and R.R. Warner. In press. Temperature, natal site and seawater chemistry affect statolith element incorporation in Kelletia kelletii larvae. Marine Ecology Progress Series.

Martin, G.B., and S.R. Thorrold. 2005. Temperature and salinity effects on magnesium, manganese, and barium incorporation in otoliths of larval and early juvenile spot Leiostomus xanthurus. Marine Ecology Progress Series. 
Ultimately, scientists need to provide

accurate information on population

\author{
connectivity, which can be used to \\ optimize spatial management approaches... \\ for marine-capture fisheries.
}

\section{3:223-232.}

Martin, G.B., S.R. Thorrold, and C.M. Jones. 2004. The influence of temperature and salinity on strontium uptake in the otoliths of juvenile spot (Leiostomus xanthurus). Canadian Journal of Fisheries and Aquatic Sciences 61:34-42.

Milton, D.A., and S.R. Chenery. 2001. Sources and uptake of trace metals in otoliths of juvenile barramundi Lates calcarifer. Journal of Experimental Marine Biology and Ecology 264:47-65.

Moran, A.L., and P.B. Marko. 2005. A simple technique for physical marking of larvae of marine bivalves. Journal of Shellfish Research 24:567-571.

Nägler, T.F., A. Eisenhauer, A. Müller, C. Hemleben, and J. Kramers. 2000. The $\delta^{44} \mathrm{Ca}$-temperature on fossil and cultured Globigerinoides sacculifer: New tool for reconstruction of past sea surface temperatures. Geochemistry Geophysics Geosystems 1: doi 10.1029/2000GC000091.

Neubert, M.G., L.S. Mullineaux, and M.F. Hill. 2006. A metapopulation approach to interpreting diversity at deep-sea hydrothermal vents. Pp. 321-350 in Marine Metapopulations. J. Kritzer and P. Sale, eds, Elsevier Academic Press.

Russo, R.E., X. Mao, J.J. Gonzales, and S.S. Mao. 2002. Femtosecond laser ablation ICP-MS. Journal of Analytical Atomic Spectrometry 17:1,072-1,075.

Sale, P.F., R.K. Cowen, B.S. Danilowicz, G.P. Jones, J.P. Kritzer, K.C. Lindeman, S. Planes, N.V.C. Polunin, G.R. Russ, Y.J. Sadovy, and R.S. Steneck. 2005. Critical gaps impede use of no-take fishery reserves. Trends in Ecology and Evolution 20:74-80. Strasser, C.A., S.R. Thorrold, V.R. Starczak, and L.S.

Mullineaux. In press. Laser ablation ICP-MS analysis of larval shell in softshell clams (Mya arenaria) poses challenges for natural tag studies. Limnology and Oceanography Methods.

Swearer, S.E., J.E. Caselle, D.W. Lea, and R.R. Warner. 1999. Larval retention and recruitment in an island population of coral-reef fish. Nature 402:799-802.

Swearer, S.E., G.E. Forrester, M.A. Steele, A.J. Brooks, and D.W. Lea. 2003. Spatio-temporal and interspecific variation in otolith trace-elemental fingerprints in a temperate estuarine fish assemblage. Estuarine, Coastal and Shelf Science 56:1,111-1,123.

Thorson, G. 1950. Reproductive and larval ecology of marine bottom invertebrates. Biology Review 25:1-45.

Thorrold, S.R., G.P. Jones, M.E. Hellberg, R.S. Burton, S.E. Swearer, J.E. Neigel, S.G. Morgan, and R.R. Warner. 2002. Quantifying larval retention and connectivity in marine populations with artificial and natural markers. Bulletin of Marine Science 70:S291-S308.

Thorrold, S.R., C. Latkoczy, P.K. Swart, and C.M. Jones. 2001. Natal homing in a marine fish metapopulation. Science 291:297-299.

Thorrold, S.R., G.P. Jones, S. Planes, and J.A. Hare. 2006. Transgenerational marking of embryonic otoliths in marine fishes using barium stable isotopes. Canadian Journal of Fisheries and Aquatic Sciences 63:1,193-1,197.
Vázquez Peláez, M., J.M. Costa-Fernández, and A. Sanz-Medel. 2002. Critical comparison between quadrupole and time-of-flight inductively coupled plasma mass spectrometers for isotope ratio measurements in elemental speciation. Journal of Analytical Atomic Spectrometry 17:950-957.

Warner, R.R., S.E. Swearer, J.E. Caselle, M. Sheehy, and G. Paradis. 2005. Natal trace-elemental signatures in the otoliths of an open-coast fish. Limnology and Oceanography 50:1,529-1,542.

Zacherl, D.C. 2005. Spatial and temporal variation in statolith and protoconch trace elements as natural tags to track larval dispersal. Marine Ecology Progress Series 290:145-163.

Zacherl, D.C., P.H. Manríquez, G. Paradis, R.W. Day, J.C. Castilla, R.R. Warner, D.W. Lea, and S.G. Gaines. 2003a. Trace elemental fingerprinting of gastropod statoliths to study larval dispersal trajectories. Marine Ecology Progress Series 248:297-303.

Zacherl, D.C., G. Paradis, and D. W. Lea. 2003b. Barium and strontium uptake into larval protoconchs and statoliths of the marine neogastropod Kelletia kelletii. Geochimica et Cosmochimica Acta 67:4,091-4,099.

Zumholz, K., A. Klügel, T. Hansteen, and U. Piatkowski. 2007. Statolith microchemistry traces the environmental history of the boreoatlantic armhook squid Gonatus fabricii. Marine Ecology Progress Series 333:195-204. 